\title{
PAKISTAN-CHINA RELATIONS: WHERE THEY GO FROM HERE?
}

\author{
Rizwan Zeb ${ }^{1}$ \\ Centre for Muslim States and Societies (CMSS), University of Western Australia
}

\begin{abstract}
:
Pakistan and China friendship, described by the leadership of both countries as higher than mountains, deeper than the oceans, and of late, sweeter than honey, is a unique case in the international system we live in, yet the relationship is based on sound geostrategic and realist calculations. An important contributing factor in the further strengthening and diversification of the relation would be how effectively both countries improve their economic relations. While this article argues that there are no chances of any problems emerging for this relationship, Islamabad needs to invest a lot more in understanding the Chinese mindset and the compulsions and limitations of the relationship. However, four issues will be important in shaping up the changing outlook of Pakistan-China relations: terrorism, security of Chinese personnel engaged in different projects in Pakistan, people to people contact and India.
\end{abstract}

Keywords: Pakista, China, Economic Relations, Terrorism, Security, People to People Contact.

\section{Resumen:}

Pakistán y China mantienen una gran relación, descrita por los líderes de los Estados como más alta que las montañas, más profunda que los océanos, más dulce que la miel así como única en sistema internacional en el que vivimos, aunque la relación está basada en la estrategia y en cálculos realistas. Un importante factor de mejora de esta relación ha sido sin duda lo efectivas que se han mostrado las relaciones económicas. Mientras que este artículo argumenta que no existen importantes problemas en la relación, Islamabad tiene que invertir más en la comprensión de la mentalidad china así como las obligaciones y las limitaciones de la relación. Sin embargo existen cuatro aspectos que tienden a configurar el desarrollo de la relación China-Pakistán: terrorismo, seguridad del personal chino implicados en diferentes proyectos en Pakistán, los contactos entre sociedades civiles y las relaciones con la India.

Palabras clave: Pakistán, China, relaciones económicas, terrorismo, seguridad, contactos "People to People”.

Copyright @ UNISCI, 2012.

Las opiniones expresadas en estos artículos son propias de sus autores, y no reflejan necesariamente la opinión de UNISCI. The views expressed in these articles are those of the authors, and do not necessarily reflect the views of UNISCI.

\footnotetext{
${ }^{1}$ Rizwan Zeb is a doctoral candidate at the Centre for Muslim States and Societies (CMSS), Department of Political Science and International Relations, University of Western Australia, and a Senior Research Analyst at the Institute for Regional Studies, Islamabad, Pakistan. He is also an Assistant Professor at the Iqra University in Islamabad, and visiting faculty at Quaid-e-Azam University. He is a former Benjamin Meaker Visiting Professor in Politics, Charles Wallace Visiting Senior Research Fellow, department of Politics, Governance Research Center, University of Bristol (2006); Visiting Scholar at the India-South Asia Project, Foreign Policy Program, Brookings Institution in Washington, DC (2004); Regional Centre for Strategic Studies (Colombo, Sri Lanka) Mahbub-ul-Haq Fellow (2003-4); and member, International Institute for Strategic Studies, London (current), Australia Institute of International Affairs (current) and South Asian Studies Association of Australia (current). He is co-author of Indo-Pak Conflicts: Ripe to Resolve? (Manahor, 2005), and is presently working on a book on the strategic culture of Pakistan.

The author wishes to thank Professor Alberto Priego, a leading China expert of Pakistan, Mr. Ghulam Ali and the reviewers for their comments on an earlier draft.
}

E-mail: srizwanzeb@gmail.com.

http://dx.doi.org/10.5209/rev_UNIS.2012.n29.4065] 


\section{Introduction}

Pakistan and China celebrated 2011 as a year of friendship to mark 60 years of the diplomatic relations. Pak-China friendship, which is described by the leadership of both countries as higher than mountains, deeper than the oceans, and of late, sweeter than honey, is a unique case in the international system we live in. ${ }^{2}$ The Pakistan-China relationship is however, not based on love or romance as many would have us believe but on sound geostrategic and realist calculations. This is exactly why the decision makers on both sides need to continuously work on it. However, it is undeniable that the bilateral relationship is unique in a number of ways. Perhaps Israel-US relationship is only relationship such provides such parallels. At the same time, should we take its smooth continuity as a given? Would Islamabad and Beijing ever decide to part ways or lose warmth in their relationship? In keeping with a number of developments at regional and international levels, are there any challenges which both sides need to address to make this friendship stronger? Or in other words, what lies ahead for Islamabad and Beijing?

The relations between the two countries were established in 1950 when Pakistan decided to recognize the People's Republic. However, the relations got strengthened in later 50s and 60s and since then both countries have cooperated and supported each other on various forums. China ended Pakistan's search for a balancer in its relations with India. Both countries exchange high-level visit regularly. China provides Pakistan with economic, military and technical aid and assistance and on its part; Pakistan supports China on issues of Tibet, Xinjiang, human rights etc. Pakistan played a pivotal role in bringing US and China together and arranged a secret visit of Kissinger to smooth things and then President Nixon visit to China. ${ }^{3}$ Pakistan also supported and assisted China in establishing contacts with the Muslim world.

Pakistan and China are collaborating in a number of sectors especially defense, trade and developmental and energy sector. Since 1960s, China has been the most important supplier of military goods to Pakistan. The JF-17 Thunder is the hall mark of this defense cooperation. Other than that both countries have collaborated in establishing munitions factories, China has provided technical assistance in improving and modernizing existing facilities. Both countries have also cooperated in a nuclear energy sector and have organized joint military exercises and officers from both countries attend courses at military institutions.

Economic trade between Pakistan and China are increasing at a rapid pace and a free trade agreement has been signed. China has also pointed that it will increase its investments in Pakistan and is currently investing in various projects related to development of infrastructure. Such as power plants, building of roads, gold and copper mines, electricity and power and nuclear plants. From 2007 to 2010, the Chinese investment was expected to increase from $\$ 4$ billion to $\$ 15$. The most important commonly known joint project is the deep sea port of Gwadar.

However, there are a number of issues which require immediate attention to avoid any further complication for the relationship prime amongst them is the issue of ETIM and its terrorist activities in Xinjiang area. There is a view, held by a number of Pakistan and China watchers that China is concerned about Chinese Uighur separatists finding a safe haven in

\footnotetext{
2 "Pakistan and China: Sweet as Can Be?", The Economist, 12 May 2011, at http://www.economist.com/node/18682839.

${ }^{3}$ Smith, Paul: "The China-Pakistan-United States Strategic Triangle: From Cold War to the "War on Terrorism", Asian Affairs: An American Review, vol. 38 (2011), pp.199, 202.
} 
Pakistan's tribal areas. On July 18, 2011, a series of bomb blasts and knife attacks happened in Hotan, Xijiang. The Muslim militants accepted the responsibility for these attacks. Chinese officials pointed out that these militants were trained in the Pakistani tribal areas. Islamabad and Beijing are already working closely on anti-terrorism issues but Islamabad should needs to address this even more carefully.

While this paper argues that there are no chances of any problems emerging for this relationship, Islamabad needs to invest a lot more in understanding the Chinese mindset and the compulsions and limitations of the relationship. At present, China is working hard to achieve its goal of emerging on the global scene as a major power by 2050 and is perhaps not willing to let anything come in its way which can create difficulties to achieve this goal. China shares the geostrategic understanding on various regional issues with Pakistan such the distrust for India and USA. But an open confrontation with any of them, in the Chinese understanding, would hinder its struggle to achieve the above stated objective. While it will continue Pakistan in various sectors and old and new projects, JF-17 fighter aircraft deal, Gwadar, Chashma nuclear power plants etc. but it would ignore its own objective while doing so. A perceptive analyst, Dr. Farukkh Saleem, a few years back aptly wrote: the new Peking Man has a singular goal -- to double, triple and quadruple China's \$4 trillion GDP by 2050. And, any country that can help China go where it wants to go is a friend -- or you are on your own. $^{4}$

Instead of focusing on a single aspect of the Pakistan and China relationship, the paper provides an overview. This has been done intentionally so that the paper can be readable and accessible to not only the experts of the South Asian affairs but general readership including students. The aim is to provide the readership basic background information on it.

This paper argues that the bilateral relationship is on firm grounds but needs further efforts to strengthen the economic relations and people to people contact. It is a surprise that such close allies until recently had almost non-existent people-to-people contact and/ or tourist activity. The paper is divided into three main parts: first part scans through the history of the bilateral relations, second looks at the relationship since 2000 and third analyzes the India factor in the relationship and what areas Pakistan and China need to address to further improve the alliance.

\section{Historical Analysis}

Pakistan despite being aligned with the western block was among the first countries to recognize China in 1950. In 1951, formal diplomatic relations were established between Pakistan and China. Pakistan was the first Muslim and third non-communist country to establish diplomatic relations with China. ${ }^{5}$ The Bandung conference in 1955 provided the first proper opportunity to the leadership of the both countries to interact. ${ }^{6}$ Pakistani Prime Minister, M. A. Bohgra took this opportunity to assure the Chinese leadership that Pakistan

\footnotetext{
${ }^{4}$ Dr Farrukh Saleem , "Capital suggestion”, 31 May 2009, at http://www.thenews.com.pk/TodaysPrintDetail.aspx? ID=215632\&Cat=9\&dt=12/27/2009

5 For details see, K. Arif, (ed.) (1984): China Pakistan Relations Documents, Lahore, Vanguard, Bhola, P. (1986): Pakistan-China Relations, Jaipur: R.B.S.A publishers; Syed, Anwar (1974): China \& Pakistan, Amherst, UMP.

${ }^{6}$ W. M. Dobell: "Ramifications of the China-Pakistan Border Treaty", Pacific Affairs, vol. 37, no.3 (1964), p. 283.
} 
has no hostile designs towards China and has joined military alliances such as SEATO and CENTO for their threat perception towards India and that it will not take part in any action against China, if it were to happen. The Chinese leadership accepted this position and in 1956, Pakistan's then Prime Minister Hussain Shaheed Suhrawardy visited China in October and Chinese Prime minister Zhou En Lai visited in December. ${ }^{7}$

Despite these visits, things were a bit slow between the two countries as both countries were part of different block and also due to the fact that the decade of 1950s was the decade of Hind-Chinney bhai-bhai (Indians and Chinese are brothers). Another reason for this was the then Pakistani Prime Minster Suhrawardy's declaration that communism is a major threat for the world. Mr. Suhrawardy visited United States of America in July 1957. After the meeting with the American president the joint communique or statement issued stated that both sides agreed that the biggest threat to the free world is international communism and that they will continue to strengthen collective measures and systems to address this problem. China, being one of the major communist countries obviously felt unhappy.

Both countries then went through a rough patch. According to a recent study, in 1959, General Ayub was shown a Chinese map which showed a large Pakistani area as Chinese territory. ${ }^{8}$ It further states that in September 1959, a few minor border skirmishes also took place between Pakistan and China in the Hunza border area. This was the reason behind Ayub Khan's offer of joint defense to Nehru as by that time, both China and India were out of the romanticism of Punj Shela and Hind-Chiney bhai-bhai. Nehru, however, shrugged off the joint Ayub's defense pact offer by stating: against whom?

On the diplomatic front, Pakistan voted for a resolution condemning Chinese excesses in Tibet. However, the relationship soon took a different turn, a development which resulted in the establishment of one of the most unique bilateral relationship in international history. The deterioration of India-China relations which eventually resulted in a border war between the two and American over all support to India ${ }^{9}$ brought Pakistan and China together.

In 1961, Pakistan voted for the restoration of China's rights in the United Nations. In a significant development, Pakistan and China signed a border agreement on March 2, 1963. Both countries signed an agreement on border relations, and the construction of a road linking China's Xingjian- Uygur autonomous region with the northern areas of Pakistan. In 1963, Pakistan and China signed their first trade agreement. Since then the bilateral relationship progressed and high level diplomatic exchanges increased significantly. During the 1965 Pakistan-India war, China came to the aid of Pakistan and provided it necessary support. This played an important role in the improvement and further cementing of Pakistan-China relations and this also ended Pakistan's search for a reliable source of aid and support in its rivalry against India. The aid was also important as it was given at a time when Pakistan's treaty partner, USA halted arms aid to both Pakistan and India.

The split in the communist world and the USSR-China Ussuri river war of 1969 divided the communist bloc. The United States of America decided to take advantage of this situation and decided to make friendly overtones to China. As it had no link with the Chinese, it

\footnotetext{
${ }^{7}$ Ibid.

${ }^{8}$ Akhtar Shahzad: "Sino-Pakistani Relations: An Assessment”, Institute of Strategic Studies Islamabad, at http://www.issi.org.pk/old-site/ss_Detail.php?dataId=501.

${ }^{9}$ Smith, op.cit, p. 201.
} 
requested Islamabad to facilitate the contact. Islamabad facilitated Henry Kissinger's secret visit to China. ${ }^{10}$

Chinese leadership was sympathetic towards Pakistan during the 1971 crisis and civil war. While it supported Pakistan, it also suggested cautious approach in addressing the problem. In the wake of the 1971 crisis between Pakistan and India, China provided economic, political and moral support to Pakistan to overcome the traumatic situation that had emerged as a result of the separation of East Pakistan which became Bangladesh. In 1972, China in support of Pakistan used its veto in the United Nations Security Council against the move to recognize Bangladesh's independence.

Bhutto is credited to be the architect of the Pak-China friendship as the foreign minister of Pakistan during the Ayub era. During Zulfiqar Ali Bhutto's era, Pakistan-China relations were on solid footings. Bhutto was a student of Socialism and regularly donned a Mao cap which became his signature cap.

During this phase of the bilateral relationship, both countries were supportive of each other. ${ }^{11}$ The relationship was mutually beneficial as both sides provided critical support to each other. In response to China's support to Pakistan, Islamabad also provided critical support to China. Islamabad played a bridge between China and the Muslim world, it played a major role in bringing USA and China together, PIA was first non-communist country airline to operate to and from China. It also significantly contributed in breaking China's isolation.

\subsection{The Rise of the Reformists in China}

An important develop of the 1970s is the rise of the reformists and pragmatics in the Chinese leadership under the leadership of Deng Xiaoping. The reformists believed that China needs to focus on economic development and tone down the ideological rhetoric. Once the reformist held the helm of the affairs in China, they brought a number of changes to Chinese policies, internally as well as externally. It was under the reformists that the country was finally opened up to the world and started taking steps to improve relations in the wider region. ${ }^{12}$

Under Deng, China started improving its relations with India. A noted Pakistani China experts is of the view that it was under Deng, China adopted a neutral stance towards the South Asian region in general and towards Indo-Pakistan conflicts in particular. Beijing also toned down its vocal support to Pakistan on the Kashmir issue and gradually shifted from support of the right to self-determination for the Kashmiri people to a peaceful solution of the issue. ${ }^{13}$ The then foreign minister of India, Atal Bahari Vajpayee visited China in 1979. The visit was a success and was followed by a number of visits between the two countries. However, it took another nine years before the then Indian Prime Minister; the late Rajiv Gandhi visited China in December 1998.

A group of analysts were of the view that with the improvement of relations between India and China, Pakistan's relations with China would be adversely effected as threat from

\footnotetext{
${ }^{10}$ For detailed account of this see; Aijzuddin, F. S. (2000)_From a Head, Through a Head, To a Head The Secret Channel Between The US and China through Pakistan, Karachi, OUP.

${ }^{11}$ Afridi, Jamal and Bajoria, Jayshree: "China-Pakistan," 6 July 2010, at http://www.cfr.org/china/chinapakistan-relations/p10070.

${ }^{12}$ See for instance Ali, Ghulam: "China's Kashmir Policy: Back to Neutrality," IPRI Journal, vol. 5, no. 2 (Summer 2005).

${ }^{13}$ Ibid.
} 
India was the driving factor/ force behind this relationship, however, as it turned out, SinoPak relations were not affected by this positive development in India-China relations. Next important development in Pakistan-China relations is the Soviet occupation of Afghanistan and the resultant international front against this and the jehad against the red army. Both Pakistan and China were in agreement on the threat that the Soviet military presence in Afghanistan posed to the security of the entire region and prepared to co-ordinate their policies to face the challenge.

In 1982, Pakistan and China established a Joint Committee for Economy, Trade and Technology in 1982. The relationship continued to be a solid one and even after the disintegration of USSR and end of the cold war, both countries continued to be formidable allies. In 1996, Chinese President Jiang Zemin paid a state visit to Pakistan during which the two countries decided to establish a comprehensive friendship. By the end of the previous century, Pakistan-China relationship was firmly established and was described as higher than mountains, deeper than oceans. Many western observers compared it with US-Israel relationship.

During the decade of 1990s, Pakistan and China continued to have good relations. Despite developments like the advent of the Taliban in Afghanistan, the two countries supported each other. While India cited the Chinese threat as the rationale behind its nuclear tests of 1998, Pakistan had extensive discussion with its allies mainly China before deciding on how to respond to the Indian tests.

General Musharraf's coup in 1999 pushed Pakistan into a diplomatic isolation. China, though not supportive of this take over, regarded it as an internal matter of Pakistan.

\section{Pakistan-China Relations since 2001}

In the aftermath of the tragic events of the 9/11, Pakistan took a $U$ turn in its Afghanistan policy and sided with the American in the WoT. Despite becoming a frontline state in the still on-going global war against terror and a non-NATO ally, Pakistan's relations with China remained strong and expanded even further. The leadership of both countries exchanged a number of high powered visits since 2000-2001 and a number of important agreements were signed. USA, often ignoring its track record of abandoning Pakistan, most recently after the Soviet withdrawal from Afghanistan and Pakistan was left alone to deal with its effects, questioned why its aid, support and help is not acknowledged by Pakistani people the way they acknowledge the Chinese help and support? Recently, Washington has expressed its displeasure on not been acknowledged for its support and help in Pakistan as China on more than one occasion. For instance, in the post-earthquake and post flood relief effort, Americans often raised the point that America is helping Pakistan the most, where are it traditional friends; China and Saudi Arabia?

Since the turn of this century, Pakistan and China continued to further strengthen their bilateral relationship. One of the most important signs of this fact is the frequently exchanged high-level visits by the leadership of the two countries. One of the most important visits by President Musharraf to China took place in February 2006. During this visit, Pakistan and 
China signed an agreement, to "build co-operation in the peaceful application of nuclear power."14

Chinese government issued special postage stamps to commemorate the 55 years of Pakistan-China diplomatic relations and the visit of the Pakistani president. During this visit, 13 agreements and Memorandums of Understanding were signed in various sectors including energy, trade, defence and communications. A general loan agreement pertaining to the use of 'preferential buyers' credit' was also signed ${ }^{15}$

In November 2006, the Chinese President Hu Jintao visited Pakistan. During this visit both countries pledged to strengthen their relations. President of Pakistan, General Pervez Musharraf was quoted as saying that "despite changes at the regional and global levels, the deep-rooted ties between the two countries have been gaining strength with the passage of time." President Hu Jintao stated that the Sino-Pakistani traditional strategic partnership would remain intact under all circumstances. He further said that the changing global scenario with critical challenges or the situation in the region will not affect the evergreen friendship, adding that Sino-Pakistani friendship was vital for prosperity and stability in the region. $\mathrm{Hu}$ also declared Pakistan as an "indispensable partner" for cooperation in the international arena. He thanked Pakistan for its continued support on the issues of Taiwan, Tibet and human rights, and for being the first country to support the anti-secession law passed by the Chinese National People's Congress in March 2005.

As per the long established tradition, after becoming the president of Pakistan, the first international destination of the President of Pakistan, Mr. Asif Ali Zardari was China. He visited China in October 2008 (October 14-17). During his visit to China, President Asif Ali Zardari discussed the state of the bilateral relationship with his Chinese counterpart, President $\mathrm{Hu}$. It was reported that both presidents agreed on taking steps to further strengthen the relationship in keeping with the changes in the region and the world.

One of the most important aspects of Pakistan-China relations is the defense cooperation between the two countries. China has been and continues to be a major source of military hardware to Pakistan. Both countries have completed a number of projects. Pakistan Ordnance Factories and the Aeronautical Complex, jointly completed Karakoram-8 (K-8) are a case in point. They have successfully tested the first flight of multi-role JF Thunder fighter airplane during Pakistan Air Chief's visit to China in May 2006. On May 23, 2006, Pakistan signed a U.S. \$ 600 million defense deal with China. According to details as part of this deal, China agreed to build four frigates for the Pakistan Navy, upgrade the Karachi dockyard and transfer the technology for indigenous production of a modern surface fleet for the Navy. Under this deal, it was decided that three out of the four frigates will be built in Shanghai, whereas the fourth would be built at the Karachi dockyard. Admiral Tahir of the Pakistan Navy, at the moment the deal was signed declared it a milestone in Sino-Pak defense cooperation especially in Navel sector. ${ }^{16}$

\footnotetext{
${ }^{14}$ Patrick Goodenough, "As India's Ties with US advance, Pakistan looks To China”, CNSNews.com, 15 March 2006, at http://www.crosswalk.com/1383933/.

15 "Joint statement between the People's Republic of China, and the Islamic Republic of Pakistan" Pakistan Ministry of Foreign Affairs, 22 February 2006, at http://www.mofa.gov.pk/press releases/2006/February/PR 73 06.htm.

16 "Pak, China finalise defence deal", The Tribune, 24 May 2006, at http://www.tribuneindia.com/2006/20060524/world.htm\#2.
} 
Despite the fact that Pakistan and China signed their first trade agreement in 1963, up till the mid-1990s, the economic relationship between China and Pakistan was almost neglected. In the latter half of the 1990s, both countries realizing this started taking some steps to improve the situation. However, the real efforts to address this started in the previous decade.

A comprehensive free trade agreement was signed in 2008, giving each country unprecedented market access to the other. The bilateral trade is somewhere between around $\$ 7$ billion to 10 billion a year according to various estimates. In May 2001, the then Prime Minister Zhu Rongji, during his visit to Pakistan, urged both sides to cooperate in various areas such as agriculture, infrastructure, information technology and other fields. A number of agreements were signed during this visit ranging different sectors such as economic and technical cooperation, tourism cooperation, lease of Saindak copper-gold project, supply of locomotives, supply of passenger coaches to railways etc. China also pledged to continue its support for the Gwadar port project and the coastal highway and agreed to provide around \$1billion to support these agreements.

Prime Minister Zhu Rongji said, "These projects are very important for the development of Pakistan. We will fully support these projects and provide help in this regard." A landmark development in the bilateral relationship was the signing of the Joint Declaration on direction of the bilateral relations in 2003 during the visit of the then president of Pakistan. This joint declaration provides a road map for the Pakistan-China relations. An important point of this document is the emphasis it puts on improving economic relations. In 2005, two years after the signing of this document, Pakistan-China trade was showing an upward trend and reached from around $\$ 1$ billion in 2000 to $\$ 4.5$ billion in 2005 , though tilted in favor of China.

During his first visit to Pakistan in April 2005, Premier Wen Jiabao also attended the China-Pakistan Business Cooperation Conference. In his address to the delegates attending the conference, he stresses on improving the bilateral economic relations. He pointed out that both countries complement each other in more than one ways. Pakistan has abundance of resources; China has the required technologies and know-how to utilize them. According to him, China will continue to work with Pakistan to improve the trade relations and will address the trade imbalance with Pakistan. He also stated that China will actively encourage the competitive enterprises to invest in Pakistan so as to achieve win-win results and create more employment opportunities in local areas. He also pointed that both countries need to further strengthen communications and exchanges and expand opportunities for business cooperation. The governments of both countries should build a platform and create opportunities to promote the establishment of cooperation and communications mechanism. He identified a number of areas for further cooperation such as agriculture, finance, science and technology and stressed that such cooperation should include joint venture, sole foreign ownership, lease, training and contracting explored actively so as to inject new vitality to China-Pakistan economic and trade relations.

According to media reports, during President Musharraf's visit to China, both countries signed an agreement to promote bilateral trade and co-operation, and a general loan agreement regarding the use of 'preferential buyer's credit'. It was also reported that China would invest $\$ 12$ billion in projects in Pakistan, as well as another $\$ 500$ million in a joint venture company ${ }^{17}$

\footnotetext{
17 "China, Pakistan agree on basic terms of free trade pact" Xinhua, 17 May 2006, at http://www.bilaterals.org/spip.php?article4764
} 
The cooperation between the two countries is wide-ranging and covers various areas and sectors. Both countries are actively cooperating in infrastructural built-up especially in Pakistan. Both countries are cooperating on projects that include highways, gold and copper mines, major electricity complexes and power plants, and numerous nuclear power projects. It is estimated that around ten thousand Chinese experts, engineers and workers are engaged in 120 projects in Pakistan. By 2010, it was estimated that the total Chinese investment which includes heavy engineering, power generation, mining, and telecommunications was around $\$ 15$ billion.

One of the most significant joint development projects of recent years is the major port complex at Gwadar, located in the Pakistani province of Balochistan. Gwadar port complex was inaugurated in December 2008 and now fully operational, provides a deep-sea port, warehouses, and industrial facilities for more than twenty countries. China was involved in the project from the very beginning and was its main financer. It also provided major technical assistance during various stages of its construction. The project is of immense strategic importance as Gwadar is strategically located. The port is just 180 nautical miles from the Strait of Hormuz, through which 40 percent of all globally traded oil is shipped. Gwadar provides China access to the Persian Gulf and an opportunity to diversify and secure its crude oil import routes through the Arabian Sea especially for its Xingjian region.

Since the beginning of this century, Islamabad is working hard to project and make Pakistan an Energy and Trade corridor for the region. It has taken a number of steps in this regard. Bothe countries agreed to cooperate in achieving this objective. A memorandum was signed between China and Pakistan, where both countries agreed to step up co-operation in the energy sector, promising to give China access to the gas and oil resources of Central and Western Asia. Islamabad pointed that China should build direct pipelines to Karachi or Gwadar, where this would then be the shortest route for ensuring a stable and fast supply of oil to China. "We particularly look forward to materializing cooperation in the energy sector where establishment of oil refineries, oil storage facilities and gas pipelines stand out," said then President of Pakistan General Musharraf, adding "When the Karakoram Highway was built, the world called it the eighth wonder, we can create the ninth and tenth wonders by establishing energy pipelines and railway linkages between the two fast growing economies."

Although the trade figures between the two countries are on the rise but they continue to be in favor of China. Pakistani business community is of the view that the Chinese traders and businessmen invest in only those areas which favors them and would make quick profits, operating from China and is not interested in investing in areas that can help Pakistani business community. The business community is also not sure of the rationale behind the Free Trade Agreement (FTA) that was signed in 2006 and became operational in January 2007. The leadership of both countries will have to address this issue for the smooth functioning of the economic relationship in the days ahead. ${ }^{19}$

With Pakistan's transition to democracy and after the assumption of the office of the President of Pakistan, Asif Ali Zardari's visited China, October 14-17, 2008. During this visit, both countries vowed to push their friendship to new heights. China reaffirmed its

\footnotetext{
${ }^{18}$ Niazi, Tarique: “Gwadar: China's Naval Outpost on the Indian Ocean”, The Jamestown Foundation, vol. 28 February 2005, at http://www.jamestown.org/single/?no_cache=1\&tx ttnews\%5Btt news\%5D=3718.

19 Fazal-ur-Rahman : "Pakistan-China trade and investment relations*," Paper presented at the seminar on Pakistan-China Relations - 2011: Year of Friendship, organised by the Institute of Strategic Studies, Islamabad, (11-12 January 2011), at http://issi.org.pk/publication-files/1299822989 45060000.pdf .
} 
commitment to advance strategic partnership with Pakistan. During the visit, 11 agreements, memorandums of understanding and protocols to enhance bilateral cooperation in trade, energy, infrastructure, agriculture, industry, mining, telecommunication, disaster relief and space technology were signed. China also promised to help Pakistan ward off financial disaster with a soft (i.e., low-interest) loan of $\$ 500$ million.

As for long-term economic goals, President Zardari had the Planning Commission of Pakistan work out an economic charter that is charged with helping grow bilateral trade between Beijing and Islamabad, as well as in attracting Chinese investment.

\subsection{India Factor}

It would be inappropriate to ignore the India factor in the Pakistan-China relations. Many call it a triangular relationship. In fact a number of Indian strategic thinkers and commentators, state that Pakistan reacts to Indian actions where as India keeps an eye on China as it is its main threat. Especially since the 1998 nuclear tests, India is increasingly projecting itself as a counterweight and challenger to the Chinese influence in the region. However, it would be an exaggeration to state that India was the sole reason for Pakistan and China to come together. At the time, when Pakistan and China were getting closer, there were a number of factors at play. For instance, Pakistan's search for a reliable source of military hardware and economic support, increasing rift between USSR and China, successful settlement of the boundary issue between Pakistan and China. Therefore, while one cannot ignore the India factor in brining Pakistan and China together, it would be erroneous to state it as the sole reason for PakistanChina alliance.

India and China started off as friendly states during the 1950s when Nehru was championing the non-aliened movement. Nehru's socialist leanings and belief that India is destined to play a major role at the global level brought India and China closer. It was the time of the Hind-Chinney Bhai-Bhai and the Punj-Shelas. However, the romance remained shorted lived and soon resulted in active hostility between the two countries which resulted in a border war in which India was militarily humiliated by the Chinese army. Nehru never recovered from this.

However, when Deng Xiaoping took over, China moderated its stance on matters India and Pakistan and since then India-China relations have improved a lot. Since the end of the cold war, their relationship has further improved. At present, Sino-India bilateral trade stands at nearly US $\$ 60$ billion, and both countries want to reach the target of US $\$ 100$ billion by the end of 2015. Yet there are unresolved issues between the two countries: the boundary dispute, the Tibetan issue and continued Indian hospitality to the Dalai Lama, and the rivalry between the two countries for regional supremacy.

The salient features of the Chinese policy towards India can be summed up in the following: ${ }^{20}$

1. The first and foremost compelling factor is the linkage between China's strategic goals and foreign policy objectives. Modernization, national reunification and safeguarding world peace while pursuing common development are the three tasks the People's Republic of China (PRC) has set itself in the unipolar world. For its economic

\footnotetext{
${ }^{20}$ Khokhar, Amna Yusaf: "Sino-Indian relations: implications for Pakistan", Paper presented at the seminar on Pakistan-China Relations - 2011: Year of Friendship, organized by the Institute of Strategic Studies, Islamabad, (11-12 January 2011), at http://issi.org.pk/publication-files/1299745166 57265659.pdf.
} 
development, as Premier Wen Jiabao put it, "needs international environment of longterm stability and a stable surrounding environment;" the principle of peace in the periphery ${ }^{e e}$ in the interest of development has thus been the watchword for China in conducting its South Asia policy, particularly towards India.

2. The second factor concerns the overall need felt by Beijing to respond to the perceived US regional strategy to contain China with the objective of constraining its rise. Growing US-India relations are being viewed as reminiscent to the US Cold War era strategy of containing the Soviet Union. By economically engaging India, China wants to attract India towards its orbit.

3. The third factor pertains to the relevance of improvement in Sino-South Asian relations to New Delhi's ties with East and South-East Asian nations. These States are important for China in terms of strategy, trade, markets and resources.

4. Since 1994, the PRC became a net importer of oil. China, currently, imports onethird of its oil supplies, which account for as much as seven per cent of the world oil demand at 5.46 million barrels a day. India, on the other hand, imports as much as twothirds of its oil needs, consuming about 2 million barrels a day - which could increase to 7.4 million barrels a day by 2025. Good relations with India, an Indian Ocean power, seem to give an insurance to China in the matter of security of oil transportation, considering the fact that the latter imports 50 percent of its oil needs from the Middle East via the Indian Ocean, and 80 per cent of its total imports pass close to India's southern coast through the Strait of Malacca.

While China is maintaining relations with India without affecting its relationship with Pakistan, India, of late is trying to convince China to distant itself from Pakistan. The new vision of India as a global power given by the triangle of Jaswant Signh, Brajesh Mishra and George Fernandes under the leadership of A. B. Vajpayee has changed India's China policy. According to this view:

... India also began developing pressure points to make Beijing see the wisdom of winding down its entente cordiale with Pakistan. There were several elements to New Delhi's effort to pry Beijing away from Islamabad: explicit identification of China and especially the Sino-Pakistani entente cordiale as the reason for Indian nuclearization in mid-1998; raising the issue of Sino-Pakistani relations in the newly initiated security dialogue; using India's Look East policy to expand Indian security ties with China's neighbours; and establishing a strategic partnership with the United States as a way of repaying China in kind for its links to Pakistan. Pressuring China was not the only objective in any of these policy thrusts, but in each case it was one important objective. ${ }^{21}$

\footnotetext{
${ }^{21}$ Garver, John W.: "The Future of the Sino-Pakistani Entente Cordiale," in Michael R., Chambers, (ed.,) (2002): South Asia 202: Future Strategic Balances and Alliances, Carlisle, PA, Strategic Studies Institute, U.S. Army War College, at http://www.strategicstudiesinstitute.army.mil/pdffiles/00105.pdf.
} 
At the moment, China and India are cooperating in a number of areas and are major trading partners. However, one should ignore the fact that despite sharing short to medium term economic interests, both India and China view each other as long term rivals. Since its second nuclear tests in 1998 and seeking American alliance, India has been quite vocal about this fact. It is projecting itself as a balancer to the rising influence of China and that China is its major military rival and threat. General K. V. Krishna Rao, a former Chief of Army Staff of the Indian Army, stated, "China is the real enemy not Pakistan. We are capable of finishing Pakistan with ease." According to analysts, the Indian Intermediate Range Ballistic MissilesAgni II, for instance-would primarily target China, though these missiles are also capable of attacking sites in Southeast Asia, Afghanistan, Central Asia as well as American bases in the Indian Ocean. $^{22}$

Therefore those who are of the view that with the improvement of Sino-India relations, Pakistan will be affected as China will no more act as the balancer between the two, their view fails the test of scrutiny. Even during the initial phases (1980-1990s) of improvement of relations between China and India, Pakistan continued to receive high power delegates from China; it also received important military and civilian aid and hardware during this period. Since the turn of the new century, the strategic fault lines in Southern Asia and the larger Indian Ocean region have become crystal clear. India has made a choice and is open about it. India and China are rivals whether it is in the energy and resource sector, be it in Central Asia or Africa, in the Indian Ocean and Asia.

Sino-Pak relations have over the years evolved and are no more restricted to just defence and military side. India, even if it ever was, is no more the defining factor of SinoPakistan relationship and it is highly unlikely that China will ignore or abandon Pakistan for the sake of India in the foreseeable future.

\section{Reflections and Conclusions}

Pakistan continues to be vital for China. Pakistan can become a geographical impediment to America's China-containment policy. Both share threat perception towards India. They are also cooperating on containing the East Turkestan Islamic Movement, which China believes is struggling to create an independent Islamic state in Xinjiang. For Pakistan, China is a major supplier of military hardware, nuclear reactors and a counter leverage to the US.

NUS Professor Huang Jing once opined that Pakistan needs China more than China needs Pakistan. This might have been the case for most of the history of the bilateral relationship between Pakistan and China; however, this is likely to change.

Since the border agreement between the two countries which was the actual starting point of this unique relationship in modern history, both countries have been through thick and thin and have supported each other. Although the relationship was unbalanced as China was stronger and bigger in every aspect yet both countries have been vital to each other. If China has been a major source of military hardware and financial assistance to Pakistan, Pakistan was the only window and contact China had with the outside world. It acted as a bridge between China and the Muslim world. It has supported Chinese position on the issues of Tibet, Taiwan and the Xinjiang province and stood by it when the world criticized China

\footnotetext{
${ }^{22}$ Ali, Ghulam: “China’s Kashmir Policy: Back to Neutrality”, IPRI Journal, vol. 5, no. 2 (Summer 2005).
} 
for alleged human right violations. Therefore, it would be appropriate to point that both countries have supported each other and this is why the relation continues to be higher than the mountain and deeper than the oceans, using the way most of the leadership of the two countries define it.

An important document was signed during President Musharraf's visit to China in November 2003; Joint Declaration on Direction of Bilateral Relations provides a route map of how to take the relationship into the years and decade ahead. An important aspect of this declaration is that it emphases the strengthening of the economic relations between the two countries while further strengthening the already existing cooperation and bonds. In 2005, China and Pakistan signed a landmark Treaty of Friendship and Cooperation, whereby they committed that neither party will join any alliance or bloc which infringed upon the sovereignty, security and territorial integrity of either nation. Both sides also agreed that they would not conclude treaties of this nature with any third party.

However, this is also a fact that emphasis has been on security related issues and the economic side of the relationship was largely neglected until recently. However, with the turn of this century, both countries especially Pakistan has started emphasizing on the economic side of the relationship (which has been covered in detail in the relevant section of the paper It makes sense for Islamabad to emphasis the economic cooperation along with military and technological cooperation. A major role in this regard will be played by the Gwadar port. Gwadar is the key to the future of Pakistan-China relations. When its full potential will be utilized, it will take the China-Pakistan relations to new heights and the comity of this allweather friendship will be ensured. At the same, Pakistan would have a new source of FDI and would then be in a position to act as the energy corridor and hub in the region. It will also provide Pakistan with a strategic advantage against its rival India.

Pakistan will expectedly generate US\$60 billion a year in transit fees in the next 20 years, and China will secure a cheaper energy route. China is now the world's second-largest consumer of oil after the US. Its consumption is expected to double by 2025, with 70 per cent coming from the Middle East. Both India and China are competing for finite supplies. Experts have already pointed out that Gwadar is the closest access point China has to the Persian Gulf. Pakistan is crucial to China's bid for regional influence.

However, four issues will be important in shaping up the changing outlook of PakistanChina relations: terrorism, security of Chinese personnel engaged in different projects in Pakistan, people to people contact and India.

China is facing a serious terrorism problem in Xinxiang. Chinese experts suspect a link between the South Asia based Jehadi groups and the East Turkistan movement. Both China and Pakistan are cooperating on this front and have an institutionalized antiterrorism dialogue and intelligence sharing mechanism. In December 2003, Pakistan Army in a military operation near the Pak-Afghan border killed Hasan Mahsum, the leader of East Turkistan Islamic Movement and arrested quite a few members of ETIM which were extradited to China. On August 6, 2004, China and Pakistan conducted their first joint antiterrorism military exercise named "Friendship 2004", in Xinjiang. However, in keeping with the Chinese sensitivity on the issue, Pakistan needs to take it very seriously and has to be addressed by both sides very carefully. Last year, for the first time, china publically blamed Pakistan for the trouble in its Xinjiang province where around 20 people we killed in a flareup in Hottan area. The state run Xinhua news agency reported that initial probe has shown that the heads of the group had learned skills of making explosives and firearms in overseas 
camps of the terrorist group East Turkistan Islamic Movement in Pakistan before entering Xinjiang to organize terrorist activities. The report was broadcasted while the then InterServices Intelligence Chief Lieutenant General Ahmed Shuja Pasha was visiting China.

Another important issue is the safety and security of the Chinese personnel engaged in different projects in Pakistan or studying or visiting. Tehreek-e-Taliban Pakistan, Baluch insurgents and Lal-Masjid brigade all have targeted Chinese nationals. A number of Chinese got killed in such attacks and many still believe that the Lal-Masjid brigade's raid on a Chinese massage parlour was the proverbial last feather on the camel's back and pushed General Musharraf for a crackdown against it. China has conveyed its concerns to Pakistan and this regard and Pakistan must ensure that all Chinese are safe and secure.

Another area, where serious focus is required is the people-to-people contact between the two countries. At present, the relationship is mostly at the state level. This needs to be changed and people-to-people interaction needs to be enhanced. In recent years, youth exchanges have increased and more and more scholars, analysts and students have visited the two countries but all this, still leaves much to be desired. Both countries must focus more on this aspect of the relationship.

In the months and years ahead, economic co-operation and the exchange of official visits between Beijing and New Delhi are likely to increase. There might be some kind of an adjustment on the issue of Sikkim and Arunachal Pradesh but as it has been stated earlier, New Delhi will continue to project china as a threat and will continue building its conventional and nuclear arsenal creating complications for strategic stability in the Southern Asia. Due to geopolitical and geostrategic compulsions, in the days ahead, India and USA's relationship will further strengthen and Pakistan and China will come even closer.

In the foreseeable future, the Pakistan-China relations will continue to remain on solid footing and will further strengthen, however, Pakistan , in keeping with its various internal problem have to learn a lot from its time-tested friend-China. Its Chinese expectations should be realistic and pragmatic. In all likelihood, china will help Pakistan complete important projects and continue existing ones such as the JF-17 fighter aircraft, Gwadar, Chashma nuclear power plants, dams on river Indus etc. however to bear the fruits of all this, Pakistani leadership has to put its house in order so that the true potential of this friendship can be realized. 